\title{
Development of Android-Based Appy Pie Learning Media on Mathematics in Elementary School
}

\author{
1*Inas Sayyida Latifa, ${ }^{2}$ Aan Subhan Pamungkas, ${ }^{1}$ Trian Pamungkas Alamsyah, \\ ${ }^{1}$ Indhira Asih Vivi Yandari \\ ${ }^{1}$ Elementary School Teacher Education Study Program, Sultan Ageng Tirtayasa University, \\ Jl. Ciwaru Raya No 25, Cipare, Serang City 42117, Banten, Indonesia \\ ${ }^{2}$ Mathematics Education Study Program, Sultan Ageng Tirtayasa University, Jl. Ciwaru Raya \\ No 25, Cipare, Serang City 42117, Banten, Indonesia \\ *Corresponding Author e-mail: 2227160021@untirta.ac.id \\ Received: May 2020; Revised: October 2020; Published: December 2020
}

\begin{abstract}
This research aimed to develop Android-based Appy Pie learning media in mathematics subjects, especially two-dimensional shape material. Moreover, to determine the validity level of the android-based Appy Pie learning media developed and to determine the students' responses after using android-based Appy Pie learning media. This research uses the 3D model (define, design, and development) as the modification result of the 4D model by Thiagarajan. The subjects of this research were 45 fourth-grade students of SDN Rawu. The result of this research is the average score of media experts validation is $91.11 \%$ which included in the "very feasible" category, the average score of material expert validation is $98.33 \%$ which included in the "very feasible" category. The average score of the students response is $91.11 \%$ that included in the "very good" category, so it can be concluded that the Android-based Appy Pie learning media is feasible to use in the two-dimensional shape material of fourth-grade.
\end{abstract}

Keywords: Appy Pie; Android; Mathematics; Elementary School

How to Cite: Latifa, I.,S., Pamungkas, A., S., Alamsyah, T., P., \& Yandari, I., A., V. (2020). Development of Android-Based Appy Pie Learning Media on Mathematics in Elementary School. Prisma Sains : Jurnal Pengkajian Ilmu dan Pembelajaran Matematika dan IPA IKIP Mataram, 8(2), 81-90. doi:https://doi.org/10.33394/j-ps.v8i2.2628

https://doi.org/10.33394/j-ps.v8i2.2628

\section{INTRODUCTION}

The rapid advancement of science and technology affects every line of life. To apply science and technology proportionally in everyday life, it takes the ability to acquire and manage science and technology. This ability requires an orderly thought process, in accordance with logic and being able to analyze every possibility that exists. Through education, humans try to survive amid the developments and challenges of the 21 st century. The competition that is increasingly dynamic and competitive makes humans compete to become quality resources both physically, psychologically and spiritually. For that, it is required the improvement in the quality of education. In order to support the improvement of education, a quality learning process is needed.

Mathematics is a field of study that supports the development of science and technology. Mathematics is defined as the symbols that have practical functions and abstract objects of study. This causes many students who have difficulty understanding and solving math problems. Students are more dominant to experience cognitive anxiety towards mathematics, especially when working on issues with high difficulty levels. In addition, students are at compromise of learning disabilities if they have low self-efficacy levels, 
especially if it concerns to the circumstantial use of mathematics. The risk of learning difficulties is also dominant experienced by students who do not spend time effectively in learning mathematics. The attention of the learning difficulties risks on mathematics is essential to ward off the failure of students to optimize their potential in the learning process. (Ardi et al., 2019)

This difficulty is also felt by the teacher in delivering information related to abstract mathematics learning. Mathematics learning can be conducted gradually starting from the concrete stage, semi-concrete stages until students are able to understand abstract mathematics learning. Mathematical concepts can be easily understood if they are concrete. The use of media by teachers aims as a tool to deliver the learning material with the expectation to facilitate teachers to deliver and achieve learning objectives. Media learning has various types of both media that are ready to be used or are deliberately designed specifically by teachers for learning purposes. There are several media including audio, visual, audio visual, and multimedia. Audio media is a media that contains sound so it can only use the hearing sense only. Visual media is media that can only display images. Audiovisual media is a mix of visual and audio media that can display images and sound simultaneously. Multimedia is media that consists of various media. "Multimedia cases intend to bring about fundamental changes in teacher education by bridging the gap between theory and practice. The use of information and communication technology in multimedia cases is expected to create a powerful and flexible learning environment"(Van Den Berg \& Visscher-Voerman, 2000) "Multimedia has the potential to create high quality learning environments, with the capability of creating a more realistic learning context through its different media. It also helps allowing a learner to take better control of the classroom especially when the class size is large. (Nusir et al., 2013)

By utilizing technology as a learning media, especially multimedia, teachers have challenges in creating learning media that have never been used to support the learning process in the classroom. The design of instructional media for elementary school students is expected to help to improve students' abilities in learning (Driyani, 2018). The problems faced by students and teachers at SDN Rawu, especially in 4th grade, namely in the implementation of mathematics learning still use textbook media or simple media. Through that media, the teacher delivers two-dimensional material and gives questions then writes them down on the writing board. Then the students copy the material and questions that the teacher has written. For students, media learning that contains multimedia visualization is considered fun and attracts students' interest, besides that students are also less interested with or conventional media. Based on a survey conducted on 39 teachers in Palembang, it was explained that "the need for the development of learning videos to facilitate teachers in teaching contextual mathematics so that it will have a good impact on learning outcomes of elementary school students. (Astika et al., 2019)

Multimedia learning media by making applications can support the learning process. "The use of android applications on two-dimensional materials improves students' learning outcomes. (Sri Mulyani, 2018). The use of smartphones will help if it is used by teachers as a learning media, especially in the midst of the current pandemic which requires students to study at home. Based on interviews with 4th-grade teachers said that they had never made ITbased learning media and had never used smartphones as the mathematics learning media in grade 4. Designing the learning applications was one of the solutions to support learning amid the current pandemic. The use of learning media conducted by (Hutabri \& Putri, 2019) (Bahari Putri et al., 2019) states that Android-based applications are suitable to use as learning media and can be implemented properly. One of the ways to do learning media innovation is by utilizing internet and smartphone facilities by creating an Aljabar learning application which is supported by science and technology development.

Various kinds of application creation sites that are easy, attractive and freely available on the internet. One of the application creation provider sites, is appypie.com. According to 
research conducted by (Driyani, 2018) states that the use of applications made through the Appy Pie site can be used as a fun learning media, especially for 1 st and 2 nd grade so the students are able to understand and deepen the learning material. Moreover, parents have a role in monitoring students in honing academic skills.

The Aljabar application is expected to be able to make Mathematics learning in elementary school become easier to understand, can be done anywhere and anytime, increase students' learning motivation compared to using conventional media and train teachers in honing creativity in the field of digital media creation. By looking at the problems that occur in the field, Android-based Appy Pie learning media will be developed on mathematics. Based on the description of the problem limitation above, the researchers can formulate the problems such as (1) how to develop Android-based Appy Pie learning media in mathematics; (2) how is the feasibility of Android-based Appy Pie learning media in mathematics; and (3) how do students respond to Android-based Appy Pie learning media in mathematics.

\section{METHOD}

This research is research and development by applying Appy Pie learning media based on android using the 3D model development research method (Three-D) modified by Triagaran's 4D model (Lawhon, 1976), namely define, design, and develop. The subjects of this research were 45 fourth-grade students of SDN Rawu. The learning media developed validated by four validators consisting of two media experts and two material expert. The instrument for validating aspects of the media, material, and student responses in this study is presented in Table 1.

Table 1. Media Expert Validation Instruments

\begin{tabular}{ll}
\hline Aspect & Indicators \\
\hline Media & View \\
& Software engineering \\
\hline Material & Content Quality \\
& Presentation of Material \\
\hline Students response & Content Quality \\
& Technical Use \\
& Instructional Quality \\
\hline
\end{tabular}

The data analysis process in this research is to compile the data that has been obtained from the questionnaire results. The expert test questionnaire (media and material) was processed using a Likert's scale, while the students' response questionnaire was processed using the Guttman's scale. The data that has been obtained is then analyzed by calculating the total score of the questionnaire results then describing the overall questionnaire results. Based on this, the categories interpretation was done based on the Guttman's scale that has been modified by (Riduwan, 2009). In Table 2, there are score criteria arranged based on their classification

Table 2. Expert Questionnaire Scale Interpretation Table

\begin{tabular}{cl}
\hline Criteria $(\%)$ & Classification of Applications \\
\hline $0 \leq \mathrm{NP} \leq 20$ & Very Not Feasible \\
$20<\mathrm{NP} \leq 40$ & Less Feasible \\
$40<\mathrm{NP} \leq 60$ & Enough \\
$60<\mathrm{NP} \leq 80$ & Feasible \\
$80<\mathrm{NP} \leq 100$ & Very Feasible \\
\hline
\end{tabular}

According to (Riduwan, 2009) The percentage score obtained is then interpreted into the categories based on Table 3 . 
Table 3. Interpretation Table of Student Response Questionnaire Scale

\begin{tabular}{cc}
\hline Criteria $(\%)$ & Classification of Applications \\
\hline $0 \leq \mathrm{NP} \leq 20$ & Very Poor \\
$20<\mathrm{NP} \leq 40$ & Poor \\
$40<\mathrm{NP} \leq 60$ & Fair \\
$60<\mathrm{NP} \leq 80$ & Good \\
$80<\mathrm{NP} \leq 100$ & Very Good \\
\hline
\end{tabular}

The indicator of success is if the media and material experts validity reaches a score of $60-80 \%$ with feasible category and $80-100 \%$ with very feasible category, while the students' response reaches a score of $60-80 \%$ is in a good category and $80-100 \%$ is in the very good category.

\section{RESULTS AND DISCUSSION}

This research produces a product of the 4th-grade android-based mathematics learning application is Aljabar (let's learn to two-dimensional figures). This application is used by teachers and students as learning support and provides easy learning anytime and anywhere so it can help to learn during a pandemic like now. The following are the steps taken in this research and development.

\section{Defining}

The curriculum analysis was conducted with the aim to review the elementary school mathematics curriculum used in SDN Rawu, Serang City. SDN Rawu Serang City implements the 2013 curriculum. With basic competencies including the ability to explain and furthermore, material analysis is conducted to determine the scope of learning material and understand the material that will be included in the application. The needed material is a two-dimensional shape including squares, rectangles, and triangles. The use of needed supporting data to make applications are the two-dimensional shapes, videos, images that support the learning media creation.

Needs analysis is conducted to analyze the types of learning media used by teachers in mathematics learning, especially in two-dimensional shape material. Based on the needs analysis results, it shows that the learning media used in mathematics learning is still conventional media and has never used a smartphone as a learning media.

\section{Designing}

The initial stage of designing the Android-based Appy Pie learning media is by creating a storyboard. The board contains the initial design of the Aljabar application product. The stages of making a storyboard aim to facilitate the learning media creation in determining the next steps. The arrangement of instruments is based on the need for product assessment. The research instrument that has been made will be tested on the experts' team as a validation sheet in assessing the Aljabar application. The instruments used were the validation instruments for media experts, material experts, and students' responses. The media experts' validation instrument consists of visual display indicators and software engineering. The material experts' validation instrument consists of indicators of content quality and material presentation. The students' response instrument consists of indicators of content quality, technical use, and instructional quality. The Product is made by utilizing a website that provides an application development service called appypie.com. The menus include the initial application display, menu, profile, competencies and indicators, learning videos, interesting facts, and quiz. The product specifications that have been made are as follows: (1) Application Name: Aljabar (let's learn to two-dimensional figures) and (2) Application Content: Initial Display (cover), Menu, Application Maker Profile, Competencies, Learning Videos, Summary, Interesting Facts, and Quiz. The view of the Aljabar application is presented in Figure 1. 


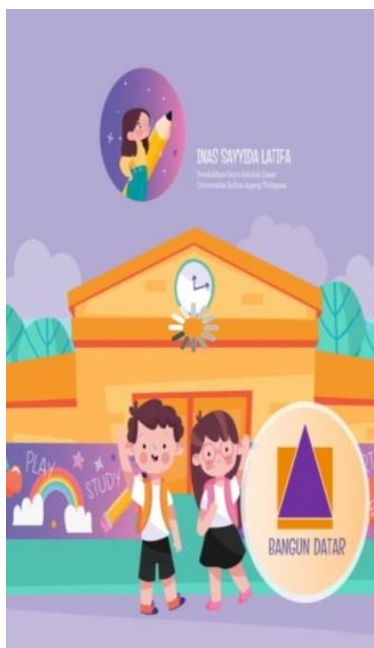

Initial Display

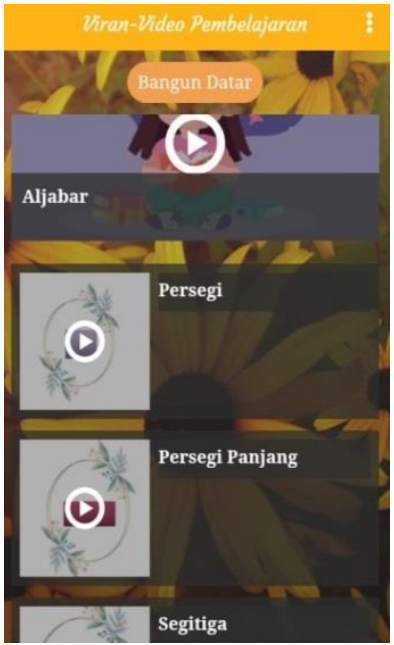

Display of Learning Videos

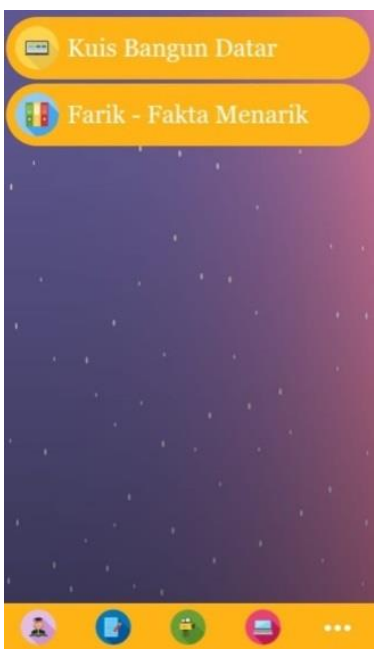

Menu Display

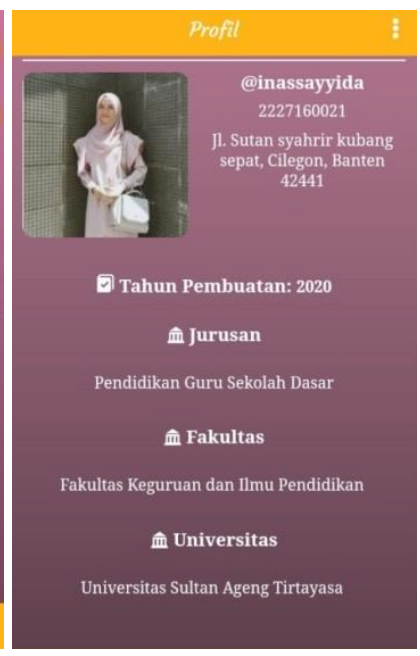

Profile Display

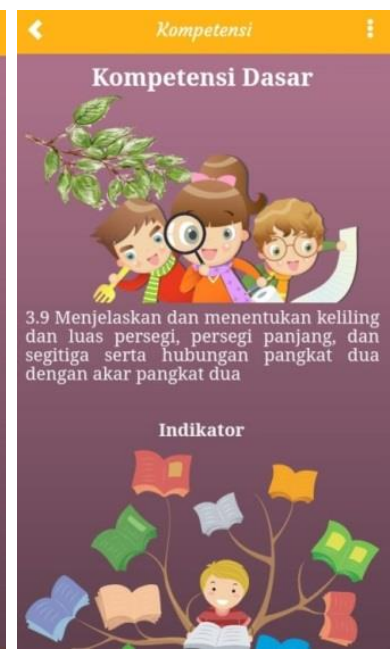

Display of Competencies

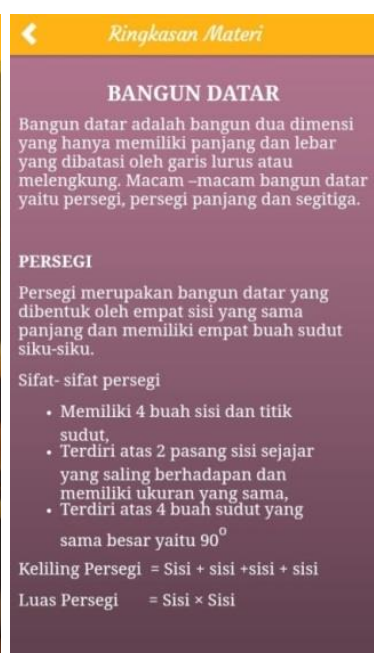

Summary View

Figure 1. Aljabar Application

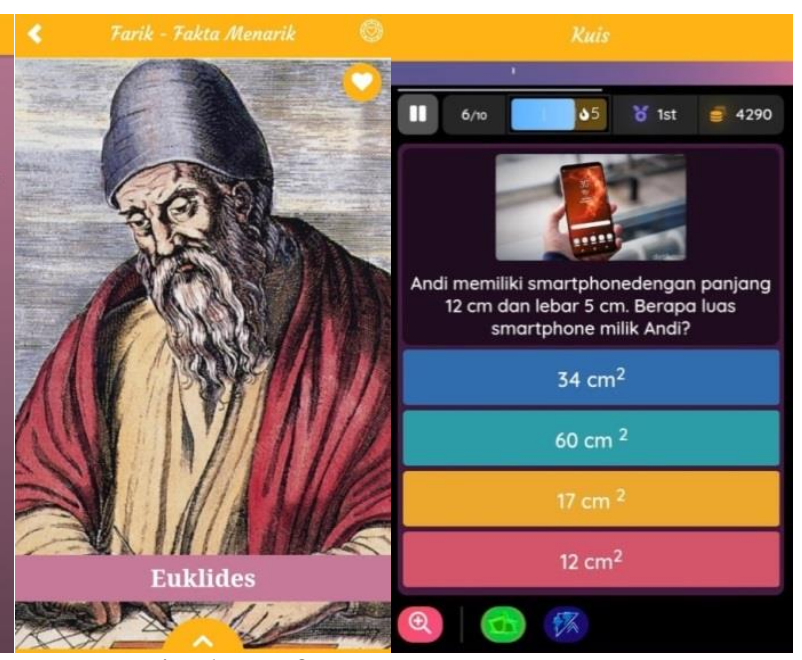

Quiz Display

Interesting Facts

\section{Development}

At the development stage, validity is conducted to determine product quality. The learning media assessment was done by four validators consisting of two lecturers as media experts, one lecturer as a material expert and one teacher as a material expert. The assessment of the media experts team in the Aljabar Application was validated by two media experts. The overall results obtained from the assessment given by the media expert's validator 1 were $84.44 \%$ with very feasible criteria, while the media expert's validator 2 was $97.78 \%$ with very feasible criteria. The average percentage is $91.11 \%$ with very feasible criteria (Table $4 \&$ Figure 2).

Table 4. Media Experts Test Results

\begin{tabular}{ccc}
\hline Validator & Percentage (\%) & Feasibility Category \\
\hline Media Experts Validator 1 & 84,44 & Very Feasible \\
Media Experts Validator 2 & 97,78 & Very Feasible \\
\hline
\end{tabular}




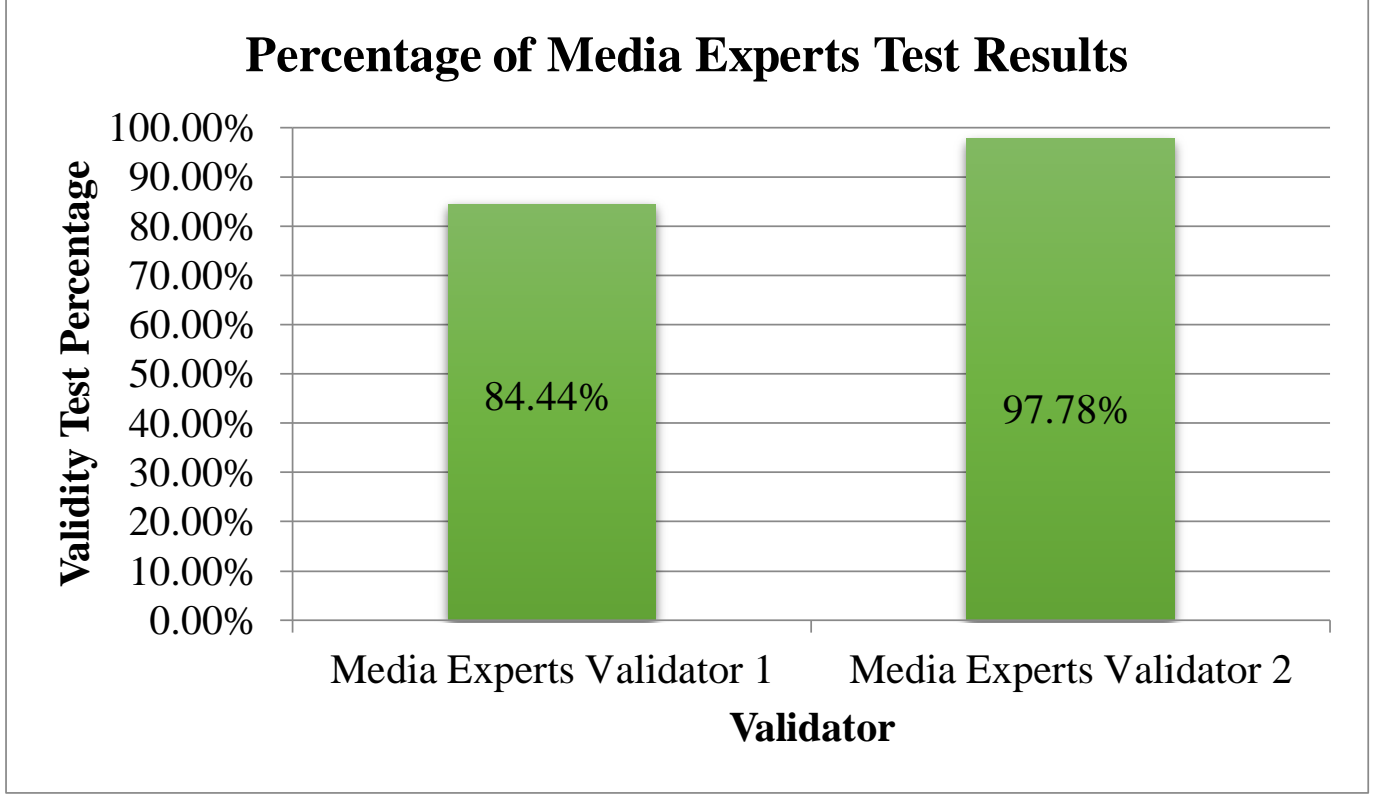

Figure 2. The Average Percentage Results of Media Experts Tests

After that, the Material Experts Assessment of Aljabar Application was validated by two material experts. The overall results obtained by the expert's validator 1 were $100 \%$ with very feasible criteria, while the material expert's validator 2 was $96.67 \%$ with very feasible criteria. The average percentage is $98.33 \%$ with very feasible criteria (Tabel $5 \&$ Figure 3 ).

Table 5. Material Experts Test Results

\begin{tabular}{ccc}
\hline Validator & Percentage (\%) & Feasibility Category \\
\hline Material Experts Validator 1 & 100 & Very Feasible \\
Material Experts Validator 2 & 96,67 & Very Feasible \\
\hline
\end{tabular}

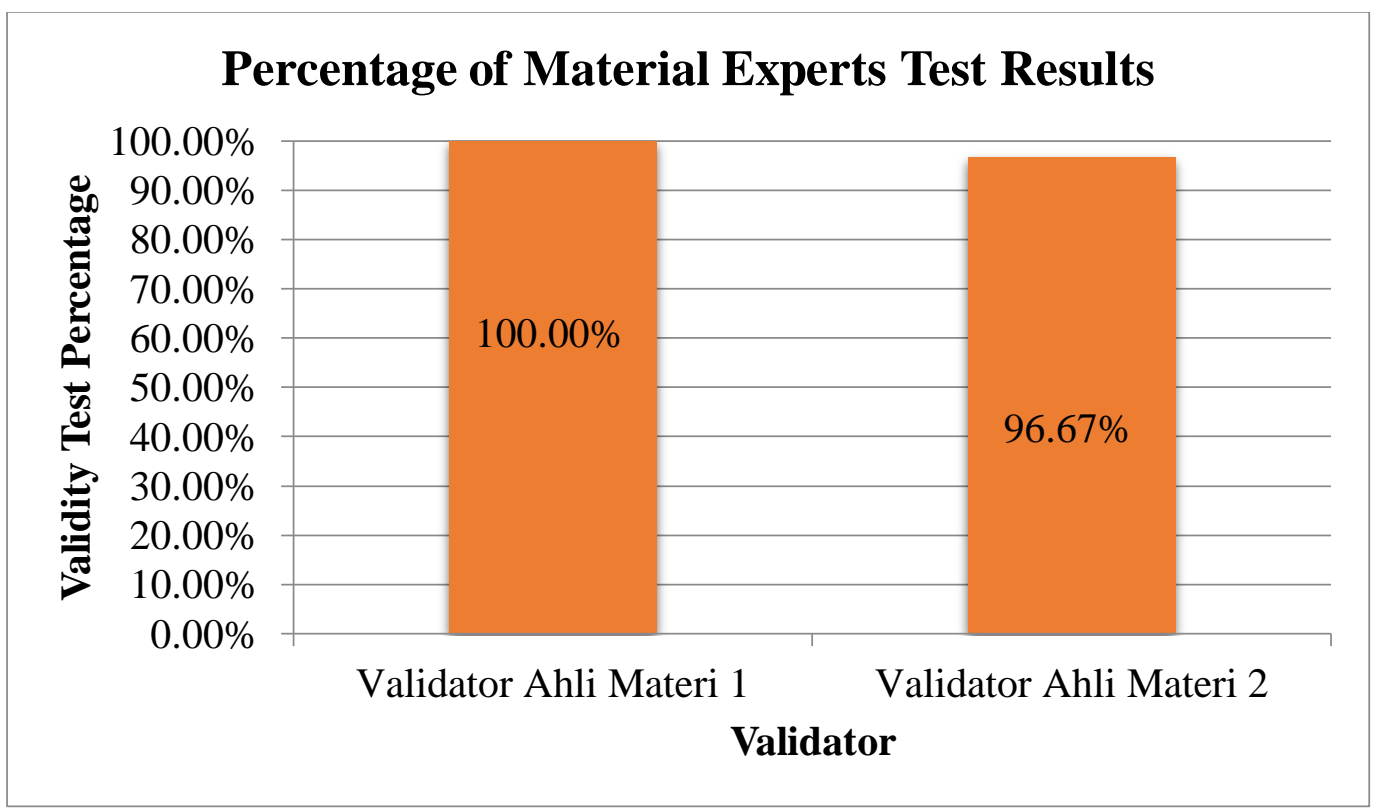

Figure 3. The Average Percentage Results of Material Experts Tests

After the validation stage by media and material experts is complete, then Aljabar application which has been tested has its weaknesses corrected based on comments and suggestions given by the experts' team. The following is the input given by the experts' team on the Aljabar application assessment: Added brainstorming videos related to twodimensional shapes, added the instructions menu for using the application, and improvement for learning video visualization of two-dimensional shapes' characters. The following are the revisions made to the Aljabar application (let's learn to two-dimensional figures) (Table 6). 
Table 6. Revision

\begin{tabular}{cl}
\hline Revision & Category \\
\hline Added hint menu & Already Done \\
Added brainstorming videos & Already Done \\
Added visualization in videos & Already Done \\
\hline
\end{tabular}

After the revision was done, a limited trial was conducted. Based on the results of students' responses to limited trials involving 45 students of grade $4 \mathrm{~A}$, it was found that the product of Ajabar was very good with a percentage of $91.11 \%$. Students state that the application is interesting and fun. The final product is an Android-based Aljabar (let's learn to two-dimensional figures) application which contains material of square, rectangular, and triangular shapes and other supporting menus.

\section{Discussion}

There are three main stages of research and development including defining, designing, and development. Development begins with defining curriculum analysis, the curriculum applied to SDN Rawu is the 2013 curriculum and determining the basic competencies. Material analysis, the next step is to collect the theories and supporting material related to the development of Aljabar applications. The results show that the material for two-dimensional shapes in 4th-grade elementary school mathematics consists of several main materials including squares, rectangles, and triangles. After analyzing the material, the final step at the defining stage is needs analysis. Needs analysis is conducted to determine the need for learning media that will support learning in the classroom. The learning media used in learning in grade 4A SDN Rawu, especially mathematics, still uses conventional media and has never used smartphones as learning media.

Designing is the second step in the research and development of Android-based Appy Pie learning media, by creating a storyboard. Making a storyboard is intended to facilitate the Android-based Appy Pie learning media design, the initial design of the product to be made will be clearly stated on the storyboard that we make. This is also explained by (Kusniyati \& Pangondian Sitanggang, 2016) designing an application aims to provide an illustration of the application to be made. The next step is to prepare an assessment instrument. This assessment instrument will be used when the experts' team will assess the initial Ajabar product. The instrument contains several statements for both the media experts' team and the material experts' team which becomes the reference for the Aljabar media feasibility. The final step in the designing stage is to produce an Aljabar application in the form of an initial product that will be tested on the experts' team. The initial product creation of Aljabar application by paying attention to the aspects that have been collected and contained in the storyboard.

Development is the final step in the development of Aljabar learning media. The development of Android-based Appy Pie learning media produces learning products in the form of an Aljabar application. The Aljabar application is designed and produced to provide opportunities for teachers to hone creativity in creating learning media, especially Androidbased, utilizing the use of smartphones as learning media in the classroom in creating the learning innovations. With this learning media, it is hoped that learning in the classroom can be held attractively, effectively, and efficiently, so students are willing to participate in learning.

The initial stage of media development is product validation. Validation involves the media experts team and material experts team. The same thing are done by (Batubara, 2017) and (Prasetyo, 2017) which in their research conducted the validation stage by involving two experts, namely material experts and media experts to ensure that the media was feasible to use. Based on the results of the validation test conducted by the experts' team, it shows that the highest average score is obtained from the validation results of material experts with a percentage score of $98.33 \%$. That score is included in the criteria of "Very Feasible" based on the criteria for interpretation categories according to (Riduwan, 2009) so the media can be 
used in schools to help the learning process. The expert team added a little note in the form of additional brainstorming information about the importance of studying the perimeter and area of the two-dimensional shapes and the presentation of the material was able to attract the students' attention in studying the learning material. Expert validation gets an average score from the media experts' validation results with a percentage score of $91.11 \%$. This score is included in the criteria of "Very Feasible" based on the criteria for interpretation categories according to (Riduwan, 2009) so the media can be used in schools to help the learning process. The expert team added a little note in the form of adding a menu of instructions for using the media, replacing images with character visualization of the two-dimensional shape.

Limited trials can be conducted after the learning media is revised according to the input given by the expert team. The limited trial aims to determine the students' responses regarding the Android-based Appy Pie learning media in the form of the Aljabar application. The implementation of a limited trial was conducted in grade 4A of SDN Rawu, Serang City with 45 students. This limited test was conducted on the basis of the cooperation of the principal and one of the grade 4A homeroom teachers at SDN Rawu, Mrs. Roihah. The implementation of the limited test begins with the distribution of a parental consent letter which contains allowing/disallowing students to bring smartphones as learning support media. Granting permission letters to parents followed by the overall media explanation, how to install applications, and spread the apk file.

The students' responses to this Aljabar application obtained an average score of $91.11 \%$ which stated that the Aljabar application was very good to use as mathematics learning media on two-dimensional shape material. Students provide comments on this application, they state that the Aljabar application is attractive and fun in learning mathematics. Regarding the same thing, it is explained in the research conducted by (Fatimah \& Mufti, 2014) that Androidbased learning media produces media with very good criteria with a percentage of $96.30 \%$. In line with that, (Ramansyah \& Brian, 2018) revealed that Appy pie is good to use because it can have a positive impact as a learning media. it is Effective to use, easy to understand, and has attractive application appearance. This is also reinforced by research conducted by (Astuti et al., 2017), that Appy Pie can be used as an Android-based learning media that is valid to use in the learning process. So it can be concluded that the use of Android-based Appy Pie learning media has a contribution and is suitable to use as a learning media.

\section{CONCLUSION}

The aims of this study have been achieved based on the findings such as: (1) Aljabar application development utilizing the appypie.com site. Development is done using a 3D model modified by Thiagarajan 4D model, namely Define, Design, to Develop; (2) The feasibility test by the media expert team obtained a percentage of $91.11 \%$ which included the very feasible criteria, the material expert team obtained a percentage of $98.33 \%$ which included in the very feasible criteria. Based on the results obtained from the feasibility test by the expert team, it was found that Appy Pie learning media is very feasible to use; and (3) Students' responses were conducted on students at SDN Rawu, Serang City, obtained a percentage of $91.11 \%$ which entered the good criteria. Based on trials by 45 students, the Appy Pie learning media can be used well in the mathematics learning process.

\section{RECOMMENDATION}

Based on the research that has been done, it is suggested for further research to take notice of the following points: (1) this application only contains two-dimensional shape material so it is hoped that further research will be able to contain other material and lessons; (2) make sure the application is installed properly on each device so the research process runs effectively and efficiently; (3) we recommend that every student should pay attention to the smartphone's storage space so it can run well when using the application; and (4) provide supporting devices such as Wi-Fi to avoid internet network limitations. 


\section{ACKNOWLEDGEMENT}

This research received no specific grant from any funding agency in the public,commercial, or not-for-profit sectors.

\section{REFERENCES}

Ardi, Z., Rangka, I. B., Ifdil, I., Suranata, K., Azhar, Z., Daharnis, D., Afdal, A., \& Alizamar, A. (2019). Exploring the elementary students learning difficulties risks on mathematics based on students mathematic anxiety, mathematics self-efficacy and value beliefs using rasch measurement. Journal of Physics: Conference Series, 1157(3). https://doi.org/10.1088/1742-6596/1157/3/032095

Astika, R. T., Astra, I. M., Makmuri, M., Sumarni, S., Andika, W. D., \& Palupi, E. K. (2019). Survey of Elementary School Teacher Needs on Video Learning Mathematics Based on Contentextual Teaching and Learning in Pelembang City. Al-Jabar : Jurnal Pendidikan Matematika. https://doi.org/10.24042/ajpm.v10i2.4936

Astuti, I. A. D., Sumarni, R. A., \& Saraswati, D. L. (2017). Pengembangan Media Pembelajaran Fisika Mobile Learning berbasis Android. Jurnal Penelitian \& Pengembangan Pendidikan Fisika. https://doi.org/10.21009/1.03108

Bahari Putri, D., Anjarwani, S. E., \& Afwani, R. (2019). Rancang Bangun Aplikasi Pendukung Pembelajaran Ilmu Pengetahuan Sosial (IPS) Sekolah Dasar Berbasis Android. Jurnal Teknologi Informasi, Komputer, Dan Aplikasinya (JTIKA ). https://doi.org/10.29303/jtika.v1i1.4

Batubara, H. H. (2017). Pengembangan Media Pembelajaran Matematika berbasis Android untuk Siswa SD/MI. MUALLIMUNA: Jurnal Madrasah Ibtidaiyah, 3(1), 12-27. https://doi.org/https://ojs.uniskabjm.ac.id/index.php/jurnalmuallimuna/article/viewFile/ 952/804

Driyani, D. (2018). Perancangan Media Pembelajaran Sekolah Dasar Berbasis Android Menggunakan Metode Rekayasa Perangkat Lunak Air Terjun ( Waterfall ). STRING (Satuan Tulisan Riset Dan Inovasi Teknologi). https://doi.org/10.30998/string.v3i1.2725

Fatimah, S., \& Mufti, Y. (2014). Pengembangan media pembelajaran IPA-Fisika smartphone berbasis android sebagai penguat karakter sains siswa. Jurnal Kaunia.

Hutabri, E., \& Putri, A. D. (2019). Perancangan Media Pembelajaran Interaktif Berbasis Android Pada Mata Pelajaran Ilmu Pengetahuan Sosial Untuk Anak Sekolah Dasar. Jurnal Sustainable: Jurnal Hasil Penelitian Dan Industri Terapan. https://doi.org/10.31629/sustainable.v8i2.1575

Kusniyati, H., \& Pangondian Sitanggang, N. S. (2016). Aplikasi Edukasi Budaya Toba Samosir Berbasis Android. Jurnal Teknik Informatika. https://doi.org/10.15408/jti.v9i1.5573

Lawhon, D. (1976). Instructional development for training teachers of exceptional children: A sourcebook. Journal of School Psychology, 14(1), 75. https://doi.org/10.1016/00224405(76)90066-2

Nusir, S., Alsmadi, I., Al-Kabi, M., \& Sharadgah, F. (2013). Studying the impact of using multimedia interactive programs on children's ability to learn basic math skills. $E$ Learning and Digital Media. https://doi.org/10.2304/elea.2013.10.3.305

Prasetyo, S. (2017). Pengembangan Media Pembelajaran Ipa Berbasis Android Untuk Siswa Sd/Mi. JMIE (Journal of Madrasah Ibtidaiyah Education), 1(1), 122-141. https://doi.org/10.32934/jmie.v1i1.29

Ramansyah, W., \& Brian, T. (2018). Pengembangan Multimedia Pembelajaran Interaktif Berbasis Appypie pada Bahasan Pengenalan Robotika Dasar. Prosiding Seminar $\begin{array}{llll}\text { Nasional Pendidikan } & \text { KALUNI, } & \text { 7(April), }\end{array}$ https://doi.org/10.30998/psnkaluni.v1i0.12

Riduwan, S. (2009). Pengantar Statistika untuk Penelitian Pendidikan, Sosial, Ekonomi, 
Komunikasi dan Bisnis. In Penerbit Alfabeta. Bandung. https://doi.org/10.1080/14789949.2017.1396487

Sri Mulyani, E. W. (2018). Dampak Pemanfaatan Aplikasi Android dalam Pembelajaran Bangun Ruang. Kwangsan: Jurnal Teknologi Pendidikan. https://doi.org/10.31800/jtp.kw.v6n2.p122--136

Van Den Berg, E., \& Visscher-Voerman, I. (2000). Multimedia cases in elementary science teacher education: Design and development of a prototype. Education and Information Technologies, 5(2), 119-132. https://doi.org/10.1023/A:1009651501532 